DOI: 10.34015/2523-4552.2021.2.03

удК 343.2

Круглов О.,

кандидат юридичних наук, доцент, доцент кафедри правознавства

Бердянського державного

педагогічного університету

ORCID:0000-0002-2266-1323

\title{
ЩОДО ПОНЯТТЯ КРИМІНАЛЬНОГО ПРАВОПОРУШЕННЯ
}

Стаття присвячена загальним проблемам неузгодженості національного законодавства у плані термінології і тлумачення окремих ключових понять кримінального права.

Ключові слова: кримінальне правопорушення; кримінально-протиправне посягання; суспільно небезпечне діяння; протиправне діяння; неправомірне діяння.

Статья посвящена общим проблемам несогласованности национального законодательства в плане терминологии и толкования отдельных ключевых понятий уголовного права.

Ключевые слова: уголовное преступление; уголовно-противоправное посягательство; общественно опасное деяние; противоправное деяние; неправомерное деяние.

Постановка проблеми. Перманентний процес удосконалення чинного законодавства, який $€$ peзультатом швидкої зміни суспільних відносин, виступає необхідною умовою підвищення ефективності його практичного застосування. Особливого значення відповідна процедура набуває у сфері кримінального права. Недоліки закону про кримінальну відповідальність можуть спричинити катастрофічні наслідки для цілої низки суб'єктів: правопорушники, потерпілі, органи досудового розслідування, судді тощо. Одним із найбільш обговорюваних у наукових і практичних колах питань виступає новела Кримінального кодексу України, яка 3 першого липня 2020 року ввела в правозастосовний оббіг термін "кримінальне правопорушення”, як збірний по відношенню до термінів “злочин” і “кримінальний проступок”. Головною причиною для цього стала виключна завантаженість слідчих, прокурорів і суддів дрібними кримінальними справами. Відповідно їх планується розглядати у спрощеному форматі дізнання. Такий крок, безумовно, $\epsilon$ виправданим, але він призвів до необхідності комплексного перегляду i внесення термінологічних правок до цілої низки нормативних актів, які, у свою чергу, стали причиною виникнення великої кількості як внутрішніх, так і зовнішніх неузгоджень.

Аналіз останніх досліджень і публікацій. Проблемі нормативного визначення поняття “злочин”, а зго- 
дом і "кримінальне правопорушення" приділяли увагу в своїх дослідженнях багато науковців, зокрема: Ю. Александров, В. Антипов, . Борисов, М. Володько, Е. Георгиевсий, О Гуцало, В. Клименко, М. Коржанський, Н Кузнецова, М. Мельник, В. Микитчик, П. Михайленко, В. Навроцький, М. Панов, О. Пащенко, Ю Пономаренко, П. Фріс, М. Хавронюк, С. Харитонов та багато інших. Проте набуття чинності останніми змінами до Кримінального кодексу України і виникнення цілої низки проблем термінологічного характеру, які вони (зміни) спричинили, як правило залишалися до цього часу непоміченими або недостатньо дослідженими правниками, як на рівні теорії, так і на практичному рівні.

Постановка завдання. Проаналізувати положення Кримінального кодексу України, що стосуються основоположної його категорії кримінальне правопорушення, для здійснення термінологічного відмежування останнього від інших споріднених, але нетотожних понять.

Виклад основного матеріалу. Як ми вже зазначали вище, недосконалість юридичної техніки законодавця $\epsilon$ підставою для чисельних дискусій i обговорень у наукових, навчальних та практичних колах. I мова йдеться не тільки про юридичну сферу. Розгалужена система регулюючого та охоронного впливу норм права на суспільні відносини не залишає осторонь від цієї проблеми представників будь-якої спеціалізації, спеціальності та професії.

Особливого значення ця проблема набуває у кримінальному праві, яке за своєю природою представляє собою специфічну галузь права, що має найбільш суворий ін- струментарій впливу на особу порушника, його майновий стан та подальшу долю. Відсутність можливості охопити абсолютно усі термінологічні проблеми оновленого Кримінального кодексу України (далі КК України) ми пропонуємо у цьому дослідженні зупинитися на аналізі лише одного дискусійного напрямку, який потребує тлумачення, наукового обговорення та можливого вдосконалення з точки зору уніфікації - поняття та ознаки кримінального правопорушення.

Так у чинному КК України для позначення діянь, які за своєю природою $є$ кримінальними правопорушеннями, використовується декілька взаємопов'язаних, але не тотожних понять. При чому логіка їх використання іноді наводить нас на думку про те, що навіть спеціалісти можуть сприймають їх на рівні синонімічних.

У першу чергу необхідно звернути увагу на ч. 1 ст. 1 КК України, у якій зазначається, що Кримінальний кодекс України має своїм завданням правове забезпечення охорони прав i свобод людини і громадянина, власності, громадського порядку та громадської безпеки, довкілля, конституційного устрою України від кримінально-протиправних посягань, забезпечення миру i безпеки людства, а також запобігання кримінальним правопорушенням [1]. Навіть поверхневий аналіз цієї норми викликає необхідність категоріального розмежування термінів “кримінально-протиправне посягання” і “кримінальне правопорушення”. Виходячи з того, що законодавець знайшов за потрібне відокремити ці терміни, ми можемо дійти висновку про їх нетотожність. На перший по- 
гляд такий підхід може здатися обгрунтованим, адже тлумачний словник української мови визначає "посягання" (іменник) - як дію за значенням посягати (потягнутися рукою (руками) до чого-небудь; засунути руку (руки) у щось) [6, 393]. Отже під злочинним посяганням слід розуміти активну форму поведінки особи, власне дію. Але дію, яка тільки потенційно передбачає досягнення результату, на який вона була спрямована. Необхідно визнати, що протягнути руки до чого-небудь зовсім не означає одержати це щось. Своєрідна спроба або замах.

Таким чином, ми можемо зробити відразу декілька висновків. Поперше, КК України має своїм завданням правове забезпечення охорони цілої низки об'єктів від суспільнонебезпечних дій, але не бездіяльності. По-друге, такого роду дії тільки потенційно можуть завдавати шкоди вказаним у попередніх абзацах об'єктам.

У цьому сенсі для з'ясування логіки законодавця ми спробували розібратися у чому полягає відмінність між термінами “охорона" i “запобігання”, адже КК України має на меті забезпечення охорони певних об'єктів від злочинних посягань і запобігання кримінальним правопорушенням. Охорона представляє собою, сукупність дій, спрямованих на оберігання від небезпеки кого-, чогонебудь, забезпечення від загрози нападу, замаху і т. ін. [6, 825]. У той же час запобігання $є$ діями, спрямованими на недопущення, заздалегідь відвернення чого-небудь неприємного, небажаного [6, 267]. На нашу думку, вказані терміни представляють собою синоніми, які максимально наближені одне до одного за змістом. Саме тому не $є$ зрозумілим чому у КК України розмежовуються охорона від кримінально-протиправних посягань і запобігання кримінальним правопорушенням.

Якщо мова йдеться про кримінально-протиправні посягання, то з одного боку позиція законодавця $\epsilon$ зрозумілою, адже кримінальна відповідальність настає не тільки за закінчене кримінальне правопорушення, але також за замах на нього. Проте чому завданням КК України $є$ забезпечення охорони окремих об'єктів тільки від суспільнонебезпечних дій, адже посягати на щось можна лише активно?

Не додає ясності у цьому питанні і друга частина ст. 1 КК України: для здійснення цього завдання Кримінальний кодекс України визначає, які суспільно небезпечні діяння $є$ кримінальними правопорушеннями та які покарання застосовуються до осіб, що їх вчинили.

Така точка зору з необхідністю наводить нас на думку про те, що не всі суспільно-небезпечні діяння $\epsilon$ кримінальними правопорушеннями. Однією із визначальних ознак кримінального правопорушення $€$ його суспільна небезпечність і саме тому у нас закономірно виникає запитання про те, чи може суспільнонебезпечне діяння не бути злочином або кримінальним проступком?

Для відповіді на це запитання необхідно звернути увагу на нормативне визначення кримінального правопорушення. Так кримінальне правопорушення представляє собою передбачене КК України суспільно небезпечне винне діяння (дія або бездіяльність), вчинене суб'єктом кримінального правопорушення (ст. 11 КК України). 
Отже суспільно небезпечне діяння (дія або бездіяльність) набуває ознак кримінального правопорушення за умови, що воно вчиняється винним у ньому суб'єктом такого кримінального правопорушення і передбачається конкретною нормою КК України. Такого роду позиція законодавця частково не викликає критики, є зрозумілою і виправданою, що втім все ж таки залишає широке поле для розмірковувань та полеміки. На нашому рівні міркувань виникає принаймні дві групи запитань.

По-перше, за нормативним визначенням кримінальним правопорушенням вважається виключно суспільно небезпечне діяння. Приймаючи до уваги той факт, що питання визначення природи об'єкту складу злочину є доволі дискусійним і варіюється від суспільних відносин до цінностей, ми пропонуємо у рамках даного дослідження зупинитися на очевидних нормативних вказівках, які зазначаються у ч. 1 ст. 1 КК України. Так відповідна норма окреслює коло охоронюваних кримінальним законом об'єктів наступними: права і свободи людини і громадянина, власність, громадський порядок та громадська безпека, довкілля, конституційний устрій України тощо. Саме тому необхідно звернути увагу, що кримінальне правопорушення може посягати не тільки на суспільні відносини. Справа у тому, що більшість таких суспільних відносин, якщо не всі, одержують кримінально-правову охорону за умови їх попереднього правового врегулювання іншими галузями права. А отже вони перетворюються на правовідносини. Крім того, вищевикладене коло благ (цінностей) не завжди охоплюється формулою суспільних відносин.

По-друге, виникає запитання чи може в Україні бути вчинене суб'єктом кримінального правопорушення (фізична, осудна особа, яка досягла віку кримінальної відповідальності) суспільно небезпечне, винне діяння, яке злочином не $\epsilon$ ? Відповідь на це запитання, при всій її очевидності (відсутність норми КК України, яка б встановлювала відповідальність за вчинення такого суспільно небезпечного діяння), на практичному рівні фактично ставить нас у скрутне з точки зору прикладної ілюстрації становище. Теоретично, можна уявити собі нову форму вчинення небезпечного для суспільства (держави, територіальної громади тощо) діяння, яке не знаходить кримінально-правової оцінки i, відповідно, покарання на рівні КК України, але на практиці сучасна наукова думка у цій сфері фактично не залишає для виникнення таких ситуацій жодного шансу. Більш вірогідним розвитком подій у досліджуваній сфері $€$ можлива криміналізації окремих діянь, які до цього не були суспільно небезпечними, але згодом стали представляти для суспільства більшу загрозу. Наприклад встановлення кримінальної відповідальності за управління транспортними засобами у стані алкогольного, наркотичного або токсичного сп'яніння.

Остання теза змушує нас звернути увагу на ще одну проблему оновленого КК України, яка виникла у зв'язку з набуттям чинності Законом України “Про внесення змін до деяких законодавчих актів України щодо спрощення досудового розслідування окремих категорій кри- 
мінальних правопорушень" (далі Закон) [2]. Мова йдеться про чехарду 3 криміналізацією і подальшою декриміналізацією відповідальності за керування транспортними засобами в стані алкогольного, наркотичного чи іншого сп'яніння або під впливом лікарських препаратів, що знижують увагу та швидкість реакції (ст. 286-1 КК України). У якості класичного прикладу для ілюстрації випадків, коли суспільно небезпечне діяння не набуває характеру кримінального правопорушення $\mathrm{y}$ науковій літературі вказується ситуація, за якої відповідну дію або бездіяльність вчиняє неосудна особа. Неосудність $\epsilon$ обов'язковою ознакою такого елементу складу кримінального правопорушення, як суб'єкт. Це у свою чергу призводить до того, що відсутність одного з елементів складу правопорушення має наслідком відсутність останнього загалом.

Продовжуючи думку про заплутаність юридичної термінології у сучасному кримінальному праві, необхідно звернути увагу на те, що паралельно 3 терміном "суспільно небезпечне діяння" у КК України використовується декілька подібних, на перший погляд, за змістом термінів: “протиправне діяння” (ч. 5 ст. 36 КК України - протиправне насильницьке вторгнення, ст. 115 КК України - протиправне заподіяння смерті іншій людині, ст. 120 КК України - ...систематичного протиправного примусу до дій, що суперечать її волі..., ст. $369^{3}$ - протиправний вплив... тощо); "незаконне діяння" (ст. 289 КК України - незаконне заволодіння транспортним засобом); “неправомірне діяння" (ст. 200 КК України - ...неправомірний випуск або використання електронних грошей).

Продовжуючи аналіз, розпочатий у попередніх частинах даного дослідження, ми повинні звернути увагу на розуміння сутності та тлумачення змісту вказаних вище термінів.

Поверхневий профаністичний погляд на категорію "незаконного діяння" викликає запитання “про що власне йдеться у цьому випадку": про порушення виключно законів України; про порушення законів i підзаконних актів України; про порушення законів, підзаконних актів України та міжнародних договорів, згода на обов'язковість яких надана Верховною Радою України?

Приймаючи до уваги, що чинне законодавство не містить прямого визначення незаконного діяння, спробуємо зробити висновки на підставі опосередкованого аналізу деяких чинних нормативноправових актів.

На рівні окремих нормативноправових актів тлумачення вказаного терміна обмежується виключно законами. Наприклад, незаконна торгівля анатомічними матеріалами людини (ч. 4 ст. 143 КК України). "Незаконна торгівля" означає будьякий заборонений законом вид практики або поводження, що стосується виробництва, відправлення, отримання, володіння, розподілу, продажу або придбання, в тому числі будь-який вид практики або поводження, що має за мету сприяти такій діяльності [5].

Інші нормативно-правові акти передбачають можливість включення до змісту досліджуваного терміна також підзаконних актів (наказів, інструкцій тощо). Наприклад, неза- 
конна лікувальна діяльність (ст. 138 КК України). Лікування - це лікування тварин речовинами, забороненими до застосування щодо продуктивних тварин, або будь-яке інше втручання у фізіологічні процеси тварини, які впливають на хімічний та соматичний склад молока чи молозива, без відповідного дозволу 3 боку спеціаліста ветеринарної медицини [3].

I нарешті ряд нормативноправових актів включає до змісту цієї категорії міжнародні домовленості. Наприклад, "Незаконний обіг” означає імпорт, експорт, продаж, доставку, переміщення або передачу вогнепальної зброї, її складових частин і основних компонентів, а також боєприпасів до неї, з території або територією однієї держави-члена до третьої країни...[4].

Такий стан речей дозволяє зробити висновок про широке розуміння змісту терміна "незаконне діяння" як дії (бездіяльності), яка за формою або змістом не відповідає вимогам будь-якого чинного нормативно-правового акту.

Якщо звернути увагу на зміст категорії “протиправне діяння", то його аналіз навіть на поверхневому рівні (не звертаючи уваги на всі існуючі теорії праворозуміння) обумовлює наявність принаймні двох можливих тлумачень: мова йде про об'єктивне розуміння цього терміна і повинно сприйматися як посягання на право в цілому, тобто на сукупність національних норм права; мова йде про суб'єктивне сприйняття права, як міри можливої поведінки управомоченого суб'єкта - посягання на встановлені, забезпечені та охоронювані державою права окремих осіб.
У першому випадку ми з необхідністю доходимо висновку про абсолютну тотожність термінів "незаконне діяння" i "протиправне діяння", у другому - мову необхідно вести виключно про порушення прав конкретної особи (життя, здоров'я, власність тощо ), а не на інші охоронювані кримінальним законом блага (цінності).

У теорії ж кримінального права протиправність, як ознака суспільнонебезпечного діяння, як правило сприймається на рівні передбачення його конкретною нормою КК України, а саме диспозицією конкретної статті Особливої частини цього нормативного акту [7]. Відповідно, будь-яке діяння, що зазначене у Особливій частині КК України, автоматично стає злочином і набуває ознак протиправності, за виключенням окремих диспозитивних норм, які звільняють від кримінальної відповідальності. Приймаючи до уваги вказану вище презумпцію, на нашу думку, немає ніякого сенсу в описовій чистині об'єктивної сторони злочину перевантажувати іiі зайвими елементами на кшталт прикметника “протиправна.

Термін "неправомірне діяння", не будучи закріпленим нормативно, 3 нашої точки зору, $\epsilon$ найбільш вивіреним i, якщо бажаєте, витонченим у порівнянні з попередніми 3 точки зору зовнішньої форми вираження. Його головним недоліком $\epsilon$ те, що він рівною мірою може бути віднесений як до злочинів та i до адміністративних правопорушень, але 3 певними уточненнями може бути використаний у якості основоутворюючого у КК України.

Окремо треба відзначити, що останні зміни КК України у частині 
введення в, так би мовити, “обіг” терміна "кримінальне правопорушення", із виділенням у якості його різновидів "кримінальних проступків" та “злочинів", хоча і виправдано необхідністю вирішення окремих практичних проблем, проте зовсім не додає ясності і прозорості процедурі тлумачення основоположних категорій кримінального права.

Ще однією групою проблем, які виникли у зв'язку з набуттям чинності Законом, стала комплексна заміна по тексту КК України термінів “злочинний” і “злочинність” на “кримінально-протиправний” та “кримінальна протиправність” відповідно. Зрозуміло, що “старі” терміни вже не можна було використовувати у зв’язку з появою у КК України категорії “кримінальних проступків”, але їх заміна прикметником протиправний не є вдалою з точки зору доктринального тлумачення його суті. Як ми вже зазначали вище протиправність, як одна 3 ознак кримінального правопорушення, як правило сприймається на рівні обов'язкової фіксації подібного роду деліктів у КК України. Відповідно, здійснюючи таку заміну, законодавець звужує коло обов'язкових ознак кримінального правопорушення тільки до протиправності, залишаючи поза увагою усі інші.

У якості прикладу можна навести термінологічні складнощі, що виникли у Розділі VIII КК України. Назву його було змінено і виглядає вона зараз так: Обставини, що виключають кримінальну протиправність діяння. Проте вже у ст. 36 КК України (Необхідна оборона) зазначається, що остання представляє собою дії, вчинені з метою захисту охоронюваних законом прав та інтересів особи, яка захищається, або іншої особи, а також суспільних інтересів та інтересів держави від суспільно небезпечного посягання шляхом заподіяння тому, хто посягає, шкоди, необхідної і достатньої в даній обстановці для негайного відвернення чи припинення посягання, якщо при цьому не було допущено перевищення меж необхідної оборони.

Аналіз відповідних незбіжностей наводить нас на думку про категоричну неузгодженість назви цього розділу з його змістом. Закономірно виникає запитання: що собою представляє необхідна оборона? Це дії, спрямовані на захист від суспільно небезпечних чи кримінальнопротиправних посягань? Суспільна небезпечність також $\epsilon$ однією 3 обов'язкових ознак кримінального правопорушення, але не єдиною.

У цьому сенсі, зважаючи на технічну недосконалість або наявність можливості неоднозначного тлумачення проаналізованих вище термінів, виникає необхідність висвітлення авторського бачення вирішення проблем такого роду. Зрозуміло, що на теоретичному рівні можна скільки завгодно термінологічно деталізувати і відокремлювати кримінально-протиправні діяння у залежності до безкінечної кількості критеріїв, проте, на рівні КК України таке доктринальне різноманіття повинно бути спрощене та уніфіковане.

Висновки. У якості висновку ми пропонуємо поглянути на вихідну категорію кримінального права під іншим кутом зору, який, на нашу думку, дозволить дещо звузити коло наукових дискусій. Так, кримінальне 
правопорушення може сприйматися, як винне, небезпечне для охоронюваних кримінальним законом

цінностей, карне, неправомірне діяння, вчинене суб'єктом кримінального правопорушення.

\section{Список використаних джерел}

1. Кримінальний $\quad$ кодекс України
https://zakon.rada.gov.ua/laws/show/2341-14.

2. Про внесення змін до деяких законодавчих актів України щодо спрощення досудового розслідування окремих категорій кримінальних правопорушень: Закон України від 22.11.2018 p. URL: https://zakon.rada.gov.ua/laws/show/2617-19\#n125.

3. Про затвердження Вимог до безпечності та якості молока і молочних продуктів: Наказ Міністерства аграрної політики та продовольства україни від 12.03.2019 № 118. URL: https://zakon.rada.gov.ua/laws/show/z059319/ed20190312\#n32.

4. Про імплементацію статті 10 Протоколу ООН проти незаконного виготовлення та обігу вогнепальної зброї, її складових частин і компонентів, а також боєприпасів до неї, який доповнює Конвенцію Організації Об'єднаних Націй проти транснаціональної організованої злочинності (Протокол ООН про вогнепальну зброю), та про встановлення дозволів на експорт і заходів щодо імпорту та транзиту вогнепальної зброї, їі складових частин і компонентів, а також боєприпасів до неї: РЕГЛАМЕНТ ЄВРОПЕЙСЬКОГО ПАРЛАМЕНТУ І РАДИ (ЄС) № 258/2012 від 14 березня 2012 року. URL: https://zakon.rada.gov.ua/laws/show/984_005-12/ed20120314\#n61.

5. Рамкова конвенція В0О3 із боротьби проти тютюну від 21.05.2003 p. URL: https://zakon.rada.gov.ua/laws/main/897_001.

6. Словник української мови: в 11 тт. / АН УРСР. Інститут мовознавства; за ред. І. К. Білодіда. Київ : Наукова думка, 1970-1980. Т. 8. 896 с.

7. Суспільна небезпечність діяння - фундаментальна ознака поняття «кримінальне правопорушення». URL: https://lexinform.com.ua/dumka-eksperta/suspilnanebezpechnist-diyannya-fundamentalna-oznaka-ponyattya-kryminalnepravoporushennya/

O. Kruhlov, Associate Professor of Legal Courses Board, Berdyansk State Pedagogical University

ORCID:0000-0002-2266-1323

\section{On the concept of criminal offense}

The article covers main issues of inconsistency of national legislation in terms of terminology and interpretation of certain key concepts of criminal law. The shortcomings of the law on criminal liability can lead to catastrophic consequences for a number of actors: offenders, victims, preliminary investigation bodies, judges, etc. The imperfection of the legislator's legal technique is the basis for numerous discussions and discussions in scientific, educational and practical circles. And it's not just about the legal field. The ramified system of regulatory and protective impact of the law on public relations does not leave aside from this problem representatives of any specialization, specialty and profession. The concept of criminal offense, in the context of the latest amendments to the Criminal Code of Ukraine, 
has undergone several significant changes in terms of understanding its essence. However, a number of problems remain unresolved. This is mainly due to only partial changes in the specified normative act and the complex terminological inconsistency of its (the Criminal Code of Ukraine) separate parts with each other. That is why, at the practical level, a whole range of issues may arise that require additional interpretations and, accordingly, waste of time and financial costs. The main terms that are related, and which, accordingly, require delimitation, should include those defined in the Criminal Code of Ukraine: a criminal offense, a criminal offense, a socially dangerous act, an illegal act, an illegal act, an illegal act. The article proposes to look at the initial category of criminal law from a different angle, which, according to the author, will somewhat narrow the circle for scientific discussions.

To solve this problem, the author makes an attempt to give a universal definition of a criminal offense with the exception of duplicate concepts from the Criminal Code of Ukraine.

Keywords: criminal offense; criminal encroachment; socially dangerous act; illegal act; criminal behavior. 